mgr inz. Tomasz Olejniczak

mgr inz. Krystian Woźniak

mgr inz. Michat Kowalski

Instytut Pojazdów Szynowych „TABOR”

\title{
Test of rolling stock compatibility with axle counters
}

\section{Badania kompatybilności taboru kolejowego z licznikami osi}

\begin{abstract}
The article presents the problems linked to the compatibility of the rolling stock with axle counters, specifying acceptable levels of interference for selected types of sensors, and conducting research. Taking measurements on railway infrastructure requires proper preparation of both the substantive test object and measuring station. Measurements are made in accordance with a plan that takes into account all the situations in which the vehicle being tested can generate interference that may cause unstable operation of sensors, such as start-up or braking.

$W$ artykule przedstawiono problematyke zwiqzana z kompatybilnościa taboru $z$ licznikami osi, określajaca dopuszczalne poziomy zaktóceń dla wybranych typów czujników oraz przeprowadzaniem badań. Wykonywanie pomiarów na infrastrukturze kolejowej wymaga odpowiedniego przygotowania zarówno merytorycznego, badanego obiektu jak i stanowiska pomiarowego. Pomiary wykonuje się zgodnie z przygotowanym planem, który uwzględnia wszystkie sytuacje, $w$ których badany pojazd może generować zaktócenia powodujqce niestabilnq pracę czujników, takie jak rozruch czy hamowanie.
\end{abstract}

\section{Introduction}

Modern rolling stock is equipped with increasingly sophisticated electrical and electronic equipment. This allows for better handling of rolling stock and passengers comfort, and is designed to reduce operating costs and increase travel safety. The axle counters rolling stock compatibility test are to demonstrate that the vehicle does not interfere with axle counter based traffic control. The measurement results should be referred to the relevant limit values - criteria that should be unambiguous and uniform for all members of the EEC. The creation of country-specific limits should be marginal and implemented only if it is necessary to ensure rail safety.

\section{Legal aspects}

The end result of rolling stock testing is to approve the vehicle into service. Scope of the tests and requirements - evaluation criteria are contained in the Office of Rail Transport (UTK) President's Letter [1]. Confirmation of meeting the requirements of electromagnetic compatibility with railroad track side relating to train detection devices can be determined on the basis of PN-EN 50238: 2003: "Railway applications - Rolling stock compatibility with train detection devices" [2] as well as the publication of Railway Institute no. 4430/10 [3]. These are the only regulations in Poland that can be used to assess the compatibility of rolling stock with axle counters.

\section{Wstęp}

Nowoczesny tabor kolejowy jest wyposażany w coraz to nowocześniejsze urządzenia elektryczne i elektroniczne. Pozwala to zapewnić większy komfort obsługi taboru, pasażerów a także ma za zadanie ograniczyć koszty eksploatacji i zwiększyć bezpieczeństwo podróży. Badania kompatybilności taboru z licznikami osi mają dowieść, że pojazd nie zakłóca urządzeń sterowania ruchem kolejowym opartych na licznikach osi. Wyniki pomiarów należy odnieść do odpowiednich limitów - kryteriów, które powinny być jednoznaczne i jednolite dla wszystkich członków Wspólnoty Europejskiej. Tworzenie indywidualnych dla danego państwa limitów, powinno być marginalne i wprowadzane tylko wówczas, gdy jest to niezbędne dla zapewnienia bezpieczeństwa w ruchu kolejowym.

\section{Aspekty prawne}

Efektem końcowym wykonywania badań taboru kolejowego jest dopuszczenie pojazdu do eksploatacji. Zakresy badań oraz wymagania - kryteria oceny zawarte są na Liście Prezesa Urzędu Transportu Kolejowego (UTK) [1]. Potwierdzenie spełnienia wymagań kompatybilności elektromagnetycznej z częścią przytorową systemu kolejowego odnoszącą się do urządzeń wykrywania pociagu, można określić na podstawie normy PN-EN 50238: 2003: „Zastosowania kolejowe - Kompatybilność pomiędzy taborem, a urządzeniami wykrywania pociagów" [2] oraz pracy Instytutu 
The European rail transport system should, however, be based on uniform regulations that clearly describe the measurement methods, the limits and the evaluation criteria, so technical specifications CLC/TS 50238-3: 2010: "Railway applications - Rolling stock compatibility with train detection devices - Part 3: Compatibility with Axis Counters [4] have been developed. The provisions contained therein can be applied to the DC power supply as well as the newer CLC/TS 50238-3: 2013 [5] and the Technical Specification for Interoperability - Control (TSI - Control) [6], these documents are linked and refer to the European Railway Agency (ERA) - ERA/ERTMS/033281 version 1.0 [7]. This document specifies the electromagnetic compatibility requirements for $\mathrm{AC}$ power systems (Alternating Current). For DC power systems (Direct Current), compatibility requirements are an open point. Hence, the results of measurements for the above-mentioned criteria can be treated as informational only.

Disturbances emitted by the vehicle are difficult to determine, especially in terms of the direction of the magnetic field. Measurements should be made in the orthogonal coordinate system $\mathrm{X}, \mathrm{Y}, \mathrm{Z}$ for broadband emission. The following figures show the magnetic field strength limits discussed separately for each vector $(\mathrm{X}, \mathrm{Y}, \mathrm{Z})$.

Comparing the limits given in IK4430/10 [3] to the requirements of CLC/TS 50238-3: 2010 [4] and ERA/ERTMS/033281 [7], reveals that they are mostly less restrictive and do not cover the whole measurement range. On this basis, it is not possible to fully determine the conformity or non-conformity of a vehicle with traffic control systems based on axle counters in terms of magnetic field compatibility in their surroundings. Caution must be exercissed in addressing work that defines vehicle compatibility requirements with infrastructure. They should be reliably carried out and unconditionally cover all possible cases that may occur under actual operating conditions.

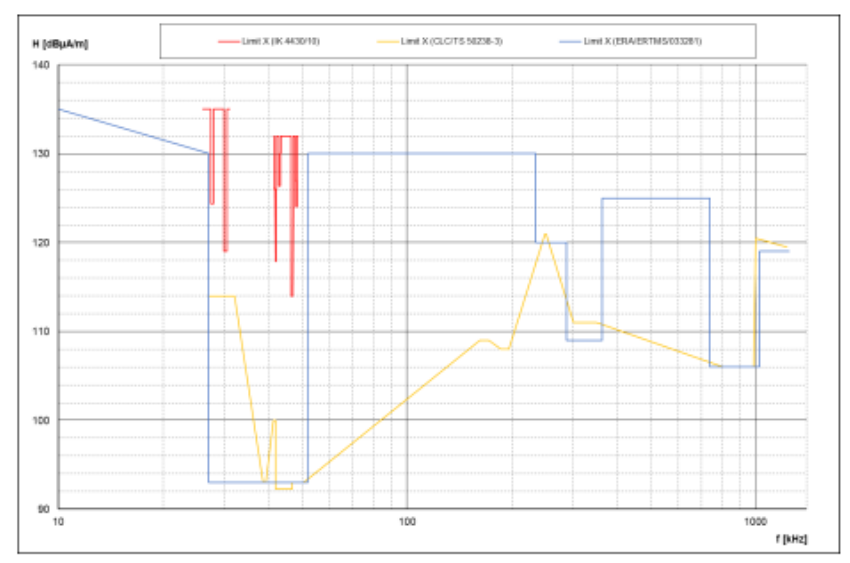

Fig. 1. Range of permissible magnetic field strength for vector $X$

Rys. 1. Zakres dopuszczalnego natężenia pola magnetycznego dla wektora X
Kolejnictwa nr 4430/10 [3]. Są to jedyne obowiązujące w Polsce przepisy według, których można oceniać kompatybilność taboru z licznikami osi.

Europejski system transportu kolejowego powinien się jednak opierać na jednolitych przepisach, które jednoznacznie opisują sposoby wykonywania pomiarów, określają limity oraz kryteria oceny wyników, dlatego opracowano techniczne specyfikacje CLC/TS 502383: 2010: „Kolejnictwo - Kompatybilność pomiędzy taborem a urządzeniami wykrywania pociagu - Część 3: Kompatybilność z licznikami osi" [4] zapisy tam zawarte można stosować do sieci zasilania DC, oraz nowszą wersję CLC/TS 50238-3:2013 [5] a także Techniczną Specyfikację Interoperacyjności - Sterowanie (TSI - Sterowanie) [6] - dokumenty te sa powiązane i odwołują się do zapisów European Railway Agency (ERA) - ERA/ERTMS/033281 w wersji 1.0 [7]. Przywołany dokument podaje wymagania kompatybilności elektromagnetycznej dla systemów zasilania w sieci AC (ang. Alternating Current). Dla systemów zasilania w sieci DC (ang. Direct Current) wymagania kompatybilności są punktem otwartym. W związku z tym wyniki pomiarów do przywołanych wyżej kryteriów można odnosić informacyjnie.

Zakłócenia emitowane przez pojazd są trudne do określenia, zarówno, jeżeli chodzi o kierunek pola magnetycznego jak i jego zwrot. Pomiary należy wykonywać w układzie współrzędnych ortogonalnych X, Y, Z dla emisji szerokopasmowej. Na poniższych rysunkach przedstawiono omówione limity natężenia pola magnetycznego, osobno dla każdego wektora (X, Y, Z).

Porównując limity podane w opracowaniu IK4430/10 [3] do wymagań zawartych w CLC/TS 50238-3:2010 [4] oraz ERA/ERTMS/033281 [7], są one w większości mniej restrykcyjne i nie obejmują całości pasma pomiarowego. Na ich podstawie nie można w pełni określić zgodności bądź niezgodności pojazdu z systemami sterowania ruchem kolejowym opartymi na licznikach osi w zakresie kompatybilności pola magnetycznego, w ich otoczeniu. Należy, zatem z dużą uwagą podchodzić do prac, które określają wymagania kompatybilności w sferze pojazd - infrastruktura. Powinny one być rzetelnie przeprowadzone i bezwarunkowo obejmować wszystkie możliwe przypadki, jakie mogą wystąpić w rzeczywistych warunkach eksploatacji.

\section{Metodyka badań}

Wykonanie pomiarów wymaga zastosowania specjalistycznej aparatury pomiarowej umożliwiającej w rzetelny sposób przeprowadzenie badań. Wytyczne odnośnie parametrów układu pomiarowego zawarto w specyfikacji technicznej CLC/TS 50238-3:2010 [4]. Układ ten zbudowany jest $\mathrm{z}$ dwóch anten pomiarowych: niskiej częstotliwości (LFR) $-10 \mathrm{kHz} \div 100$ $\mathrm{kHz}$ oraz wysokiej częstotliwości (HFR) $-100 \mathrm{kHz} \div$ 1,3 MHz, a także $\mathrm{z}$ odbiornika umożliwiającego pomiar składowych $\mathrm{X}, \mathrm{Y}, \mathrm{Z}$ pola magnetycznego. $\mathrm{Na}$ 


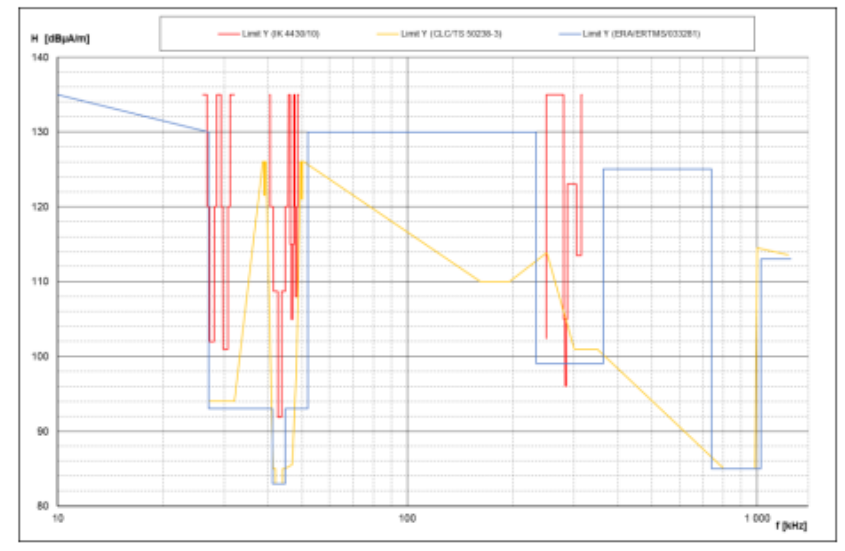

Fig. 2. Range of permissible magnetic field strength for vector $Y$ Rys. 2. Zakres dopuszczalnego natężenia pola magnetycznego dla wektora $\mathrm{Y}$

\section{Research methodology}

Performing the measurements requires the use of specialized measuring equipment allowing for a reliable test to be carried out. Guidance on measurement system parameters is contained in Technical Specification CLC/TS 50238-3: 2010 [4]. This system is made up of two measurement antennas: a low-frequency (LFR) $10 \mathrm{kHz} \div 100 \mathrm{kHz}$ and a high frequency (HFR) - 100 $\mathrm{kHz} \div 1.3 \mathrm{MHz}$, as well as a receiver for measuring the $\mathrm{X}, \mathrm{Y}$ and $\mathrm{Z}$ components of the magnetic field. Figure 4 shows the general view of the measuring antennas mounted in the track. Figure 5 shows the antennas under the vehicle during test.

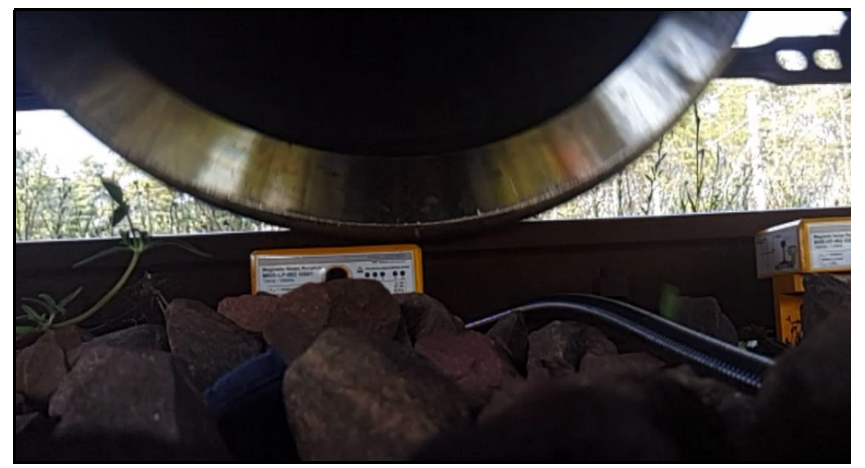

Fig. 5. View of the measuring antenna with the test vehicle passing Rys. 5. Widok anteny pomiarowej podczas przejazdu badanego pojazdu.

The test conditions described in the guidelines [4] clearly specify the test methods. The test should be carried out when passing the vehicle above the measuring antenna with maximum traction power and maximum braking force for four different speeds. During testing, all electrical and electronic equipment should be active and, if applicable, all electrical and electronic equipment should be under load.

Figures $6 \div 8$ show sample measurement results.

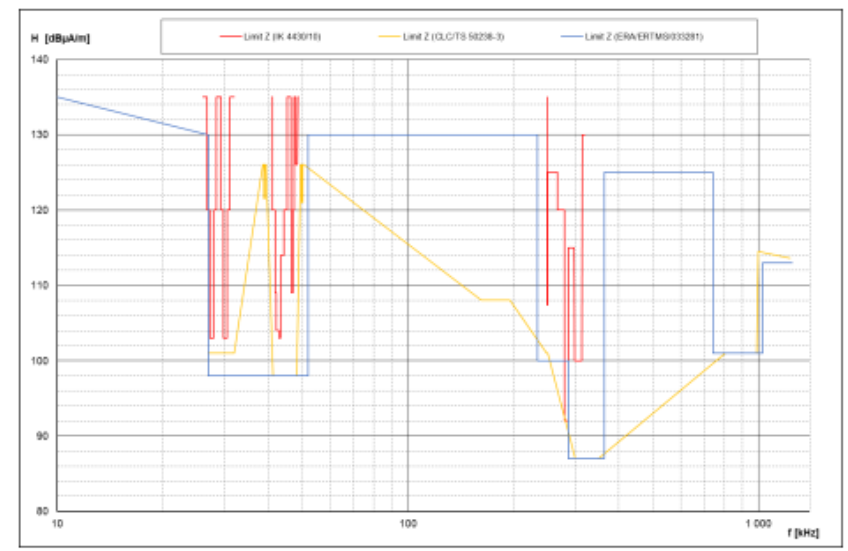

Fig. 3. Range of permissible magnetic field strength for vector $Z$

Rys. 3. Zakres dopuszczalnego natężenia pola magnetycznego dla wektora Z

rysunku 4 przedstawiono ogólny widok anten pomiarowych zamontowanych $\mathrm{w}$ torowisku. Rysunek 5 przedstawia widok anten podczas przejazdu badanego pojazdu.

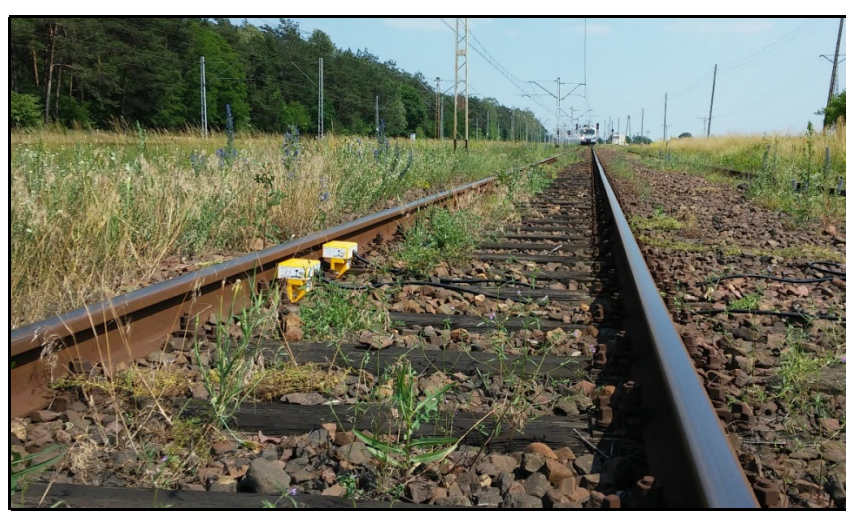

Fig. 4. General view of measuring antennas mounted in the track Rys. 4. Ogólny widok anten pomiarowych zamontowanych w torowisku

Warunki badań określone w specyfikacji [4] jednoznacznie precyzują sposoby wykonywania testów. Badania należy wykonywać podczas przejazdu pojaz$\mathrm{du}$ nad antenami pomiarowymi z maksymalną siła trakcyjną oraz maksymalną siłą hamująca, dla czterech różnych prędkości. Podczas badań powinny być załączone i w razie możliwości obciążone wszystkie urządzenia elektryczne i elektroniczne.

Na rysunkach $6 \div 8$ przedstawiono przykładowe wyniki pomiarów.

Przed i po badaniach dodatkowo wykonywany jest pomiar tła, wówczas gdy w pobliżu anten nie znajduje się żaden pojazd. Osobnym zagadnieniem jest wpływ zaburzeń emitowanych przez EZT poruszający się po sąsiednim torze na wyniki pomiarów pól magneytcznych $\mathrm{w}$ drugim torze $\mathrm{z}$ zainstalowanymi antenami. Wyniki badań porównano z pomiarami tła. 
In addition, background measurements have been performed when no vehicle was near the antennas, before and after the test. A separate issue is the impact of disturbances emitted by EZT moving along an adjacent track on the measurement results of magnetic fields in the second track with antennas installed. The results were compared with background measurements.

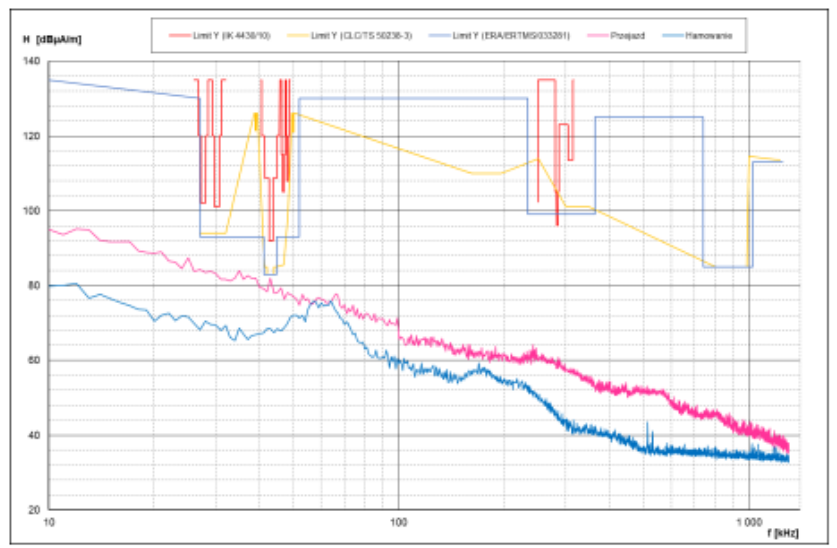

Fig. 7. Registered magnetic field strength values in the $\mathrm{Y}$ axis Rys. 7. Zarejestrowane wartości natężenia pola magnetycznego dla osi Y

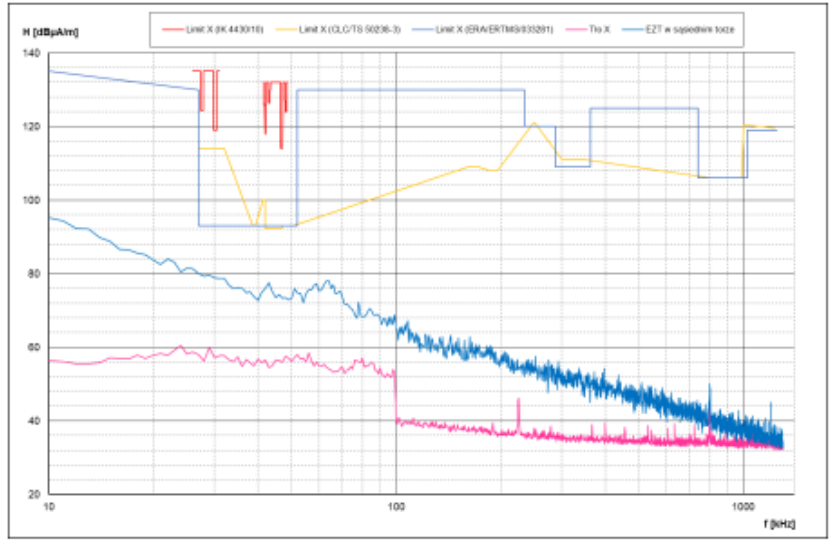

Fig. 9. Registered magnetic field strength values in the $X$ axis Rys. 9. Zarejestrowane wartości natężenia pola magnetycznego dla osi X

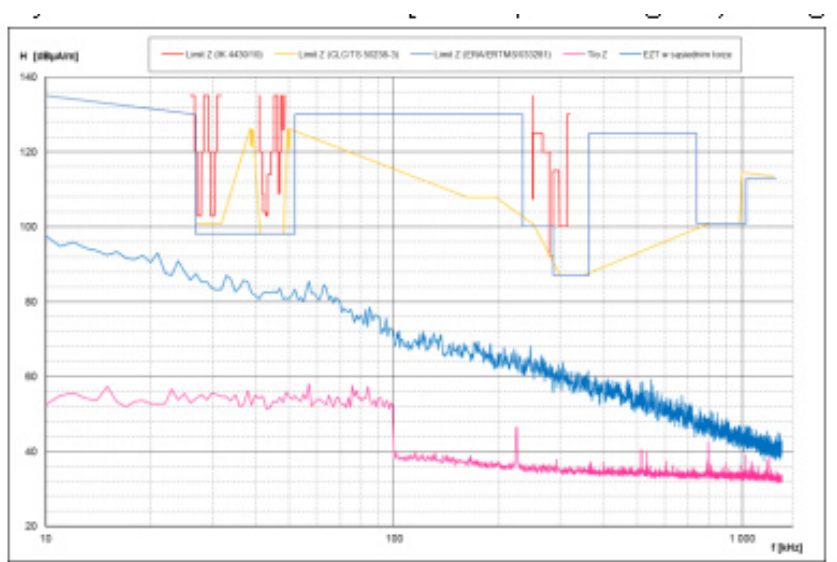

Fig. 11. Registered magnetic field strength values in the $\mathrm{Z}$ axis Rys. 11. Zarejestrowane wartości natężenia pola magnetycznego dla osi Z

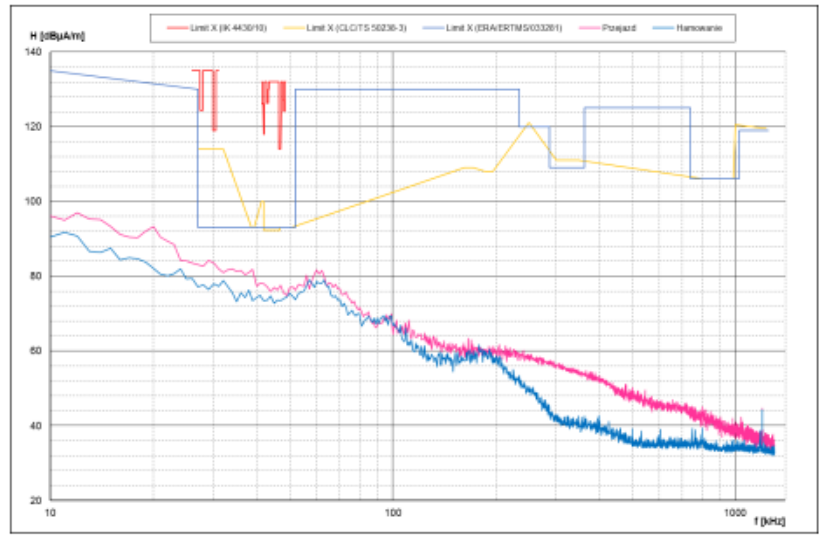

Fig. 6. Registered magnetic field strength values in the $\mathrm{X}$ axis Rys. 6. Zarejestrowane wartości natężenia pola magnetycznego dla osi X

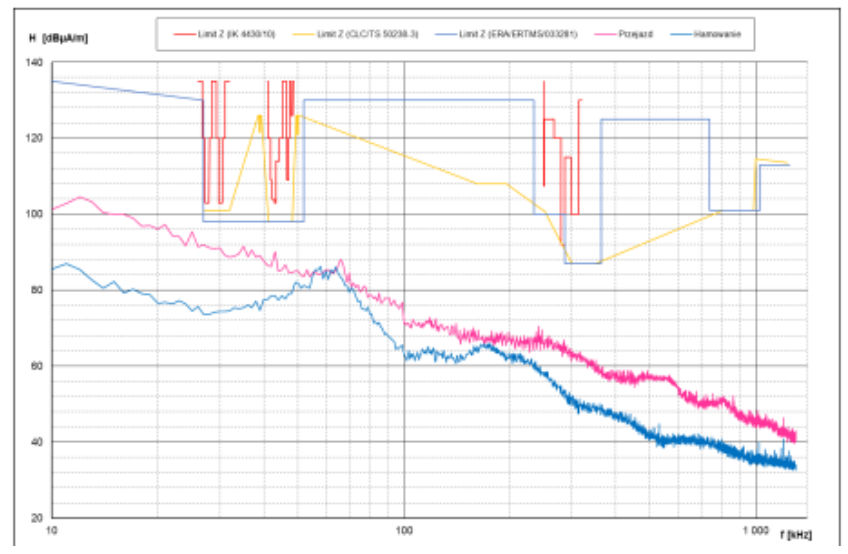

Fig. 8. Registered magnetic field strength values in the $\mathrm{Z}$ axis Rys. 8. Zarejestrowane wartości natężenia pola magnetycznego dla osi Z

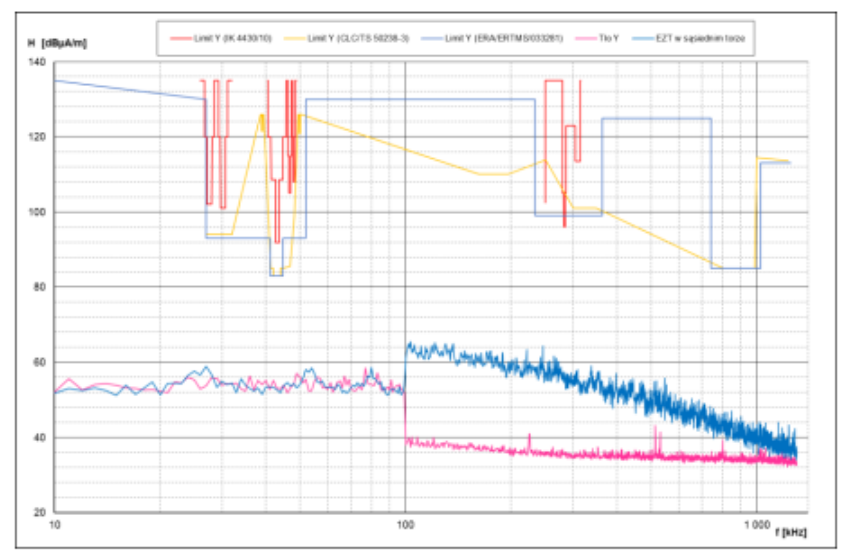

Fig. 10. Registered magnetic field strength values in the $\mathrm{Y}$ axis Rys. 10. Zarejestrowane wartości natężenia pola magnetycznego dla osi Y 
Comparing the results of a vehicle passing directly over the measuring antennas with the results of a vehicle passing along an adjacent track, it can be stated that in both cases the disturbances emitted by the passing vehicle are at similar levels. In both cases the measurement results are below the limits quoted. However, it should be assumed that two vehicles passing near wheel counters can generate disturbances in excess of acceptable limits.

\section{Conclusions}

Rail transport at both national and European level should be safe. The compatibility of rolling stock with train detection systems should be maintained under all conditions, which also means using identical and unambiguous limits for the axle counters in question. The case of a vehicle-generated disturbance in the adjacent track presented in point 3 raises the question of the current test methodology and the method of confirming compatibility. Consideration should be given to investigating what disturbances can be caused by two vehicles moving in adjacent lanes simultaneously and what affects axle counters located in one of the tracks.
Porównując wyniki pojazdu przejeżdżającego bezpośrednio nad antenami pomiarowymi $\mathrm{z}$ wynikami pojazdu przejeżdżającego po sąsiednim torze można stwierdzić, że w obu przypadkach zaburzenia emitowane przez przejeżdżający pojazd są na podobnych poziomach. W obu przypadkach wyniki pomiarów są poniżej przywołanych limitów. Należy jednak założyć, że dwa pojazdy mijające się w pobliżu liczników koła mogą generować zaburzenia przewyższające dopuszczalne limity.

\section{Podsumowanie}

Transport kolejowy zarówno na poziomie krajowym jak i europejskim powinien być bezpieczny. Kompatybilność taboru z systemami wykrywania pociagów powinna być zachowana w każdych warunkach, dlatego należy stosować jednakowe i jednoznaczne limity dla danych czujników koła. Przedstawiony w punkcie 3 przypadek zaburzenia generowanego przez pojazd przejeżdżający w sąsiednim torze stawia pod znakiem zapytania dotychczasową metodykę badań i sposób potwierdzania kompatybilności. Należy rozważyć przeprowadzenie badań mających stwierdzić, jakie zaburzenie może powstać przez dwa pojazdy poruszające się $\mathrm{w}$ sąsiednich torach $\mathrm{i}$ jaki ma to wpływ na czujniki koła znajdujące się w jednym $\mathrm{z}$ torowisk.

\section{Bibliography Literatura}

[1] Lista prezesa urzędu transportu kolejowego $w$ sprawie właściwych krajowych specyfikacji technicznych $i$ dokumentów normalizacyjnych, których zastosowanie umożliwia spetnienie zasadniczych wymagań dotyczqcych interoperacyjności systemu kolei. UTK. 2017 Warszawa.

[2] PN-EN 50238: 2003: Zastosowania kolejowe - Kompatybilność pomiędzy taborem a urządzeniami wykrywania pociagów.

[3] Białoń A., Kazimierczak A., Furman J., Zawadka L., Adamski D., Pajka P., Ortel K.: Określenie dopuszczalnych poziomów i parametrów zaktóceń dla urzadzeń sterowania ruchem kolejowym, Praca nr 4430/10. Instytut Kolejnictwa, 2011Warszawa.

[4] CLC/TS 50238-3: 2010: Kolejnictwo - Kompatybilność pomiędzy taborem a urzqdzeniami wykrywania pociagu - Część 3: Kompatybilność z licznikami osi.

[5] CLC/TS 50238-3: 2013: Kolejnictwo - Kompatybilność pomiędzy taborem a urzqdzeniami wykrywania pociagu - Część 3: Kompatybilność z licznikami osi.

[6] 2012/88/UE: 2012: Decyzja komisji z dnia 25 stycznia 2012r. w sprawie technicznej specyfikacji interoperacyjności w zakresie podsystemów „Sterowanie” transeuropejskiego systemu kolei.

[7] ERA/ERTMS/033281: 2011: Interfaces between control-command and signaling trackside and other subsystems.

[8] Zawadka L., Adamski D., Białoń A., Furman J.: Wplyw pola magnetycznego generowanego przez pojazdy trakcyjne na urzqdzenia SRK na tle obowiqzujacych standardów, Problemy Kolejnictwa, z. 168, str. 63-66, Instytut Kolejnictwa, 2015 Warszawa. 